\title{
Blood biochemical profile of four fast-growing broiler strains under high ambient temperature
}

\author{
Naila Chand ${ }^{1} \cdot$ Shabana $\mathrm{Naz}^{2} \cdot$ Ziaur $\operatorname{Rehman}^{1} \cdot$ Rifat Ullah Khan $^{3}$
}

Received: 31 January 2018/Accepted: 26 February 2018/Published online: 7 March 2018

(C) The Korean Society for Applied Biological Chemistry 2018

\begin{abstract}
The present study was carried out to evaluate the effect of optimum and high ambient temperatures on biochemical parameter of four broiler strains. Broiler chicks $(n=242)$ of four different commercial strains (Ross, Hubbard, Cobb and Arber Acer) on day 15 were divided into two groups: thermo-neutral zone (TN) group and high ambient temperature zone (HAT) group. Chicks in TN group were housed at constant room temperature $\left(25{ }^{\circ} \mathrm{C} \pm 2 \mathrm{C}^{\circ}\right.$ and $\left.\mathrm{RH} 65 \pm 5 \%\right)$ while chicks in HAT group were kept under HAT of summer. Chicks in each group were further divided into four subgroups, i.e., TNRoss, TN-Hubbard, TN-Cobb, TN-Arber Acer and HATRoss, HAT-Hubbard, HAT-Cobb, HAT-Arber Acer. Each subgroup was further subdivided into four replicates having ten chicks per replicate. Blood was collected on day 21 and 42. Mean serum aspartate aminotransferase (AST), alanine amino transaminase (ALT), alkaline phosphates (ALP), glucose, cholesterol, triglyceride, and low-density lipoprotein (LDL) were significantly higher $(P<0.05)$ in HAT group, while total serum protein and high-density lipoprotein (HDL) were significantly higher $(P<0.05)$ in TN group. In TN zone group, significantly $(P<0.05)$ lower AST, ALT, glucose, cholesterol, triglyceride, and LDL and significantly $(P<0.05)$ higher HDL and total
\end{abstract}

Shabana Naz

drshabananaz@gcuf.edu.pk

1 Department of Poultry Science, Faculty of Animal Husbandry and Veterinary Sciences, The University of Agriculture, Peshawar, Pakistan

2 Department of Zoology, GC University, Faisalabad, Pakistan

3 Department of Animal Health, Faculty of Animal Husbandry and Veterinary Sciences, The University of Agriculture, Peshawar, Pakistan protein were recorded for Cobb and Hubbard strains. In HAT zone group, significantly $(P<0.05)$ lower AST, ALT, glucose, cholesterol, triglyceride, and LDL and significantly $(P<0.05)$ higher HDL and total protein were recorded for Ross and Arber Acer strains. The findings of the present study suggested that Ross and Arber Acer strains were more tolerant to summer HAT of tropical areas than Cobb and Hubbard, while Cobb and Hubbard strains were more effective in TN environment.

Keywords Broilers · Blood B Biochemistry · Heat stress · Strains

\section{Introduction}

High environmental temperature during summer months of the year is also one of the most serious climate problems of tropical and subtropical countries of world, which exerts deleterious effects on performance of broiler chickens [1-3]. High ambient temperature and relative humidity (RH) are considered to be the most crucial factors leading to the reduction in bird's performance [3, 4].

Blood plays very important role in carrying nutrient, metabolic waste, and hormonal transmission [5-7]. The blood biochemical profile would reflect the physiological state of the body [7]. The serum biochemical profile provides valuable information about health and immune status of animals [8]. High temperature increases serum aspartate aminotransferase and alanine amino transaminase [9-11], glucose [12-14], cholesterol [15, 16], and triglyceride in broiler chicks [17]. Although the responses to heat stress differ between chickens of different genetic backgrounds $[18$, 19]. Strains selected for rapid growth are 
significantly less resistant to heat stress than strains having slow growth rate [20, 21]. Little is known about the biochemical profile of different broiler strains during heat stress; therefore, the present research study was designed to investigate the effect of high environmental temperature on biochemical profile of four different broiler strains.

\section{Materials and methods}

The study was approved by ethical committee on welfare and rights of animals, Faculty of Animal Husbandry and Veterinary Sciences, the University of Agriculture, Peshawar, Pakistan.

\section{Climatic data}

House temperature was recorded continuously during the experimental period. Temperature was recorded after every four hours in the center of the house at 08:00 am, 12:00 pm, 4:00 pm, 8:00 pm, 12:00 am, and 4:00 am, and then minimum and maximum of each day were averaged by week (Table 1).

\section{Experimental design and birds' husbandry}

The experiment was conducted in a completely randomized design with two factors, i.e., two temperature zones with four different broiler strains. A total of 240-day-old broiler chicks of four commercial broiler strains (Ross, Hubbard, Cobb, and Arber Acres) of the same age and size were used for the study. In first 2 weeks, chicks were placed in brooding room and then on day 15 , chicks were divided into two groups: thermo-neutral zone (TN) group and high ambient temperature zone (HAT) group. Chicks in TN group were housed at constant room temperature $\left(25{ }^{\circ} \mathrm{C} \pm 2 \mathrm{C}^{\circ}\right)$ and relative humidity (RH, $\left.65 \pm 5 \%\right)$ while chicks in HAT group were kept at HAT. Both the groups were kept in two different rooms, which were identical in terms of size, construction materials, and

Table 1 Mean temperature and relative humidity during the experimental period

\begin{tabular}{lll}
\hline Hour & Ambient temperature $\left({ }^{\circ} \mathrm{C}\right)$ & Relative humidity $(\%)$ \\
\hline $08: 00$ & $31.66 \pm 0.94$ & $51.65 \pm 0.32$ \\
$12: 00$ & $36.43 \pm 0.12$ & $52.29 \pm 0.91$ \\
$16: 00$ & $33.25 \pm 0.45$ & $65.32 \pm 0.47$ \\
$20: 00$ & $31.62 \pm 0.82$ & $64.43 \pm 0.78$ \\
$24: 00$ & $29.85 \pm 0.91$ & $60.67 \pm 0.82$ \\
$04: 00$ & $28.87 \pm 0.43$ & $55.22 \pm 0.11$ \\
\hline
\end{tabular}

equipments. The temperature was recorded after every four hours in the center of the house, and minimum and maximum temperature of each day were averaged per week. Chicks in each group were designated as subgroup TNRoss, TN-Hubbard, TN-Cobb, TN-Arber Acer and HATRoss, HAT-Hubbard, HAT-Cobb, HAT-Arber Acer. Each subgroup was further subdivided into four replicates having ten chicks per replicate. Feed and water were provided ad libitum. During first 21 days, chicks were provided with starter ration containing $22 \%$ crude protein (CP) and $3000 \mathrm{kcal} / \mathrm{kg}$ metabolizable energy (ME). During last three weeks, chicks were provided with finisher ration containing $20 \% \mathrm{CP}$ and $3200 \mathrm{kcal} / \mathrm{kg} \mathrm{ME}$ (Table 2). All birds of four strains were vaccinated against infectious diseases.

\section{Serum biochemical profile}

Blood samples were collected on day 21 and day 42 from randomly selected birds (one bird per replicate) for biochemical analysis. Blood was collected from the wing vein with the help of disposable syringe using 22 gauge needles. Blood samples were centrifuged at $4000 \mathrm{rpm}$ for $10 \mathrm{~min}$ for serum separation. Serum samples were analyzed for aspartate aminotransferase (AST), alanine aminotransferase (ALT), alkaline phosphatase (ALP), glucose, cholesterol, triglyceride, total protein, low-density lipoprotein (LDL), and high-density lipoprotein (HDL) using autoanalyzer (Microlab 300 semiautomated biochemical analyzer) and its accompanying kits. AST and

Table 2 Ingredient composition of starter and finisher diets

\begin{tabular}{|c|c|}
\hline Ingredients & $(\%)$ \\
\hline Maize & 60.7 \\
\hline Soybean meal & 35.6 \\
\hline Vegetable oil & 0.5 \\
\hline Limestone & 1.4 \\
\hline Dicalcium phosphate & 1.2 \\
\hline DL methionine & 0.15 \\
\hline Salt & 0.4 \\
\hline Vitamin + trace mineral premix ${ }^{1}$ & 0.3 \\
\hline Total & 100 \\
\hline \multicolumn{2}{|l|}{ Calculated nutrient composition } \\
\hline Protein & $22 \%$ \\
\hline Poultry ME (Kcal/kg) & 3000 \\
\hline \multicolumn{2}{|c|}{$\begin{array}{l}{ }^{1} \text { Each } \mathrm{kg} \text { of premix consisted of: pyridoxine, } 1 \mathrm{mg} \text {; folic acid, } \\
0.4 \mathrm{mg} \text {; molybdenum, } 0.32 \mathrm{mg} \text {; ethoxyquin, } 25 \mathrm{mg} \text {; choline chloride, } \\
60 \mathrm{mg} \text {; dI- } \alpha \text {-tocopherol acetate; } 4 \mathrm{mg} \text {; iodine, } 0.2 \mathrm{mg} \text {; thiamine, } \\
0.3 \mathrm{mg} \text {; Ca pantothenate, } 3 \mathrm{mg} \text {; cyanocobalamin, } 3 \mu \mathrm{g} \text {; biotin, } \\
0.02 \mathrm{mg} \text {; Mn, } 15 \mathrm{mg} \text {; } \mathrm{Zn}, 10 \mathrm{mg} \text {; iron, } 4 \mathrm{mg} \text {; Cu, } 1 \mathrm{mg} \text {; Co, } 0.06 \mathrm{mg} \text {; } \\
\mathrm{Se}, 0.02 \mathrm{mg} \text {; cholecalciferol, } 0.018 \mathrm{mg} \text {; trans-retinol, } 0.66 \mathrm{mg} \text {; } \\
\text { menadione, } 0.4 \mathrm{mg} \text {; riboflavin, } 1.6 \mathrm{mg} \text {; and niacin, } 6 \mathrm{mg}\end{array}$} \\
\hline
\end{tabular}


ALT were determined with the help of commercially available kits (RANDOX B, I234, and Foster City, CA, USA). Glucose was also determined with the help of commercial kit (Singapore Bioscience PTE Ltd, Singapore). Serum protein was determined according to the IFCC (International Federation of Clinical Chemistry and Laboratory Medicine) method. Cholesterol was determined by enzymatic calorimetric method with the help of commercially available kits (Tech Diagnostic Technologies, Madrid, Spain). Triglyceride (TG) was determined by enzymatic calorimetric method using analyzer with the help of commercially available kits (Linear chemicals, Barcelona, Spain). High-density lipoprotein (HDL) and low-density lipoprotein (LDL) were determined by analyzer with the help of commercially available kits (HDL and LDL/VLDL Quantification Colorimetric/Fluorometric Kits (Biovision Inc., Mountain View, CA, USA).

\section{Statistical analysis}

Data were subjected to two-way analysis of variance with temperatures and strain as the main effects. The following model was used:

$Y j k m=\mu+\beta j+\alpha k+\gamma l+e j k l m$

where

$\mu=$ population mean,

$\beta j=$ treatment effect; treatment comprised of $\mathrm{TN}$ and HAT zones,

$\alpha k=$ The strain effect (four commercial broiler strains

Ross, Hubbard, Cobb, and Arber Acres),

$\gamma l=$ The strain by temperature zone interaction,

eijklm $=$ The random error associated with $k$ th chicks and $j$ th treatment in experimental unit.

Least significant test was used to compare the differences among treatment means. All statistical analysis was carried out using statistical package of SAS [23].

\section{Results}

Mean serum AST and ALT of four different broiler strains reared in TN and HAT zones are presented in Table 3. Temperature zones significantly $(P<0.05)$ affected serum AST and ALT in different broiler strains in all recorded stages. On day 21 in TN zone, significantly $(P<0.05)$ lower AST and ALT were found in Cobb and Hubbard, while in HAT zone, no significant $(P<0.05)$ difference was recorded in mean serum AST level. On day 42, in TN zone, significantly $(P<0.05)$ lower AST level was recorded in Hubbard and was followed by Cobb, Arber Acer, and Ross, while in HAT zone, significantly $(P<0.05)$ lower AST was found in Arber Acer followed by Ross. Similarly, on day 42 in TN zone, significantly $(P<0.05)$ lower and the same ALT level was recorded in Ross, Hubbard, and Cobb. Mean ALT level of Arber Acer was not different from Ross, Hubbard, and Cobb on day 42. In HAT zone on day 42 , significantly $(P<0.05)$ lower and the same serum ALT level was recorded in Ross and Arber Acer.

Mean serum ALP and protein of four different broiler strains reared in TN zone and HAT zone are presented in Table 4. Temperature zone significantly $(P<0.05)$ affected serum ALP and protein in different broiler strains at all recorded stages. On day 21 in $\mathrm{TN}$ zone, significantly $(P<0.05)$ lower and the same serum ALP was found in Cobb and Hubbard, while in HAT zone, significantly lower $(P<0.05)$ and the same ALP level was recorded in Ross and Arber Acer followed by Cobb and Hubbard. On day 42 in $\mathrm{TN}$ zone, no significant differences were recorded in mean serum ALP levels of different broiler strains. On day 42 in HAT zone, significantly lower $(P<0.05)$ ALP was recorded in Arber Acer as compared to all other strains. In TN zone, significantly $(P<0.05)$ higher and the same serum protein was recorded for Hubbard and Cobb, while in HAT zone, significantly $(P<0.05)$ higher and the same serum protein was recorded for Ross and Arber Acer on day 21. On day 42 in HAT zone, significantly higher $(P<0.05)$ serum protein was found in Ross followed by Arber Acer, while the lowest and the same serum protein levels were recorded for Hubbard and Cobb.

Mean serum glucose of four different broiler strains reared in TN and HAT zone is presented in Table 5. Temperature zone significantly $(P<0.05)$ affected serum glucose in different broiler strains at all recorded stages. On day 21 in TN zone, significantly $(P<0.05)$ lower and the same serum glucose level was found in Cobb and Hubbard followed by Arber Acer and Ross, while in HAT zone, significantly lower glucose was recorded in Arber Acer followed by Ross. Significantly $(P<0.05)$ higher and the same glucose level was recorded in Hubbard and Cobb on day 21 in HAT zone. On day 42 in TN zone, significantly $(P<0.05)$ lower serum glucose level was recorded in Hubbard and Cobb. On day 42 in HAT zone, significantly $(P<0.05)$ lower serum glucose was found in Ross followed by Arber Acer, while significantly $(P<0.05)$ higher and the same serum glucose levels were recorded in Cobb and Hubbard.

Mean serum cholesterol and triglycerides of four different broiler strains reared in TN zone and HAT zone are presented in Table 6. Temperature zone significantly $(P<0.05)$ affected serum cholesterol and triglycerides level in different broiler strains at all recorded stages. On day 21 in TN zone, significantly $(P<0.05)$ lower serum cholesterol was found in Hubbard followed by Cobb, while in HAT zone, significantly lower and the same serum 
Table 3 Mean \pm SE aspartate aminotransferase (AST) and alanine amino transaminase (ALT) of different broiler strains reared in thermo-neutral and high ambient temperature zones

Table 4 Mean \pm SE serum alkaline phosphatase (ALP) and protein of different broiler strains reared in thermo-neutral and high ambient temperature zones

\begin{tabular}{|c|c|c|c|c|c|}
\hline \multirow[t]{2}{*}{ Zone } & \multirow[t]{2}{*}{ Strain } & \multicolumn{2}{|l|}{ AST (U/l) } & \multicolumn{2}{|l|}{ ALT (U/l) } \\
\hline & & Day 21 & Day 42 & Day 21 & Day 42 \\
\hline \multirow[t]{4}{*}{ TN zone } & Ross & $172^{\mathrm{b}} \pm 1.29$ & $265.75^{b c} \pm 3.35$ & $173.75^{\mathrm{b}} \pm 0.85$ & $237.50^{\mathrm{d}} \pm 7.18$ \\
\hline & Hubbard & $163.25^{\mathrm{c}} \pm 1.54$ & $250.25^{\mathrm{e}} \pm 7.04$ & $163.50^{c} \pm 1.04$ & $232.25^{\mathrm{d}} \pm 5.45$ \\
\hline & Cobb & $159.75^{\mathrm{c}} \pm 1.65$ & $252.75^{\mathrm{de}} \pm 4.90$ & $164.50^{c} \pm 2.75$ & $231.75^{\mathrm{d}} \pm 8.67$ \\
\hline & Arber Acer & $175.75^{\mathrm{b}} \pm 3.40$ & $264.25^{\mathrm{b}} \pm 2.28$ & $173.25^{\mathrm{b}} \pm 1.10$ & $243.25^{\mathrm{cd}} \pm 3.32$ \\
\hline \multirow[t]{4}{*}{ HAT zone } & Ross & $183^{\mathrm{a}} \pm 0.70$ & $269^{\mathrm{bc}} \pm 2.88$ & $181^{\mathrm{a}} \pm 1.080$ & $262.75^{\mathrm{c}} \pm 6.66$ \\
\hline & Hubbard & $186.25^{\mathrm{a}} \pm 3.09$ & $286^{\mathrm{a}} \pm 3.57$ & $185.25^{\mathrm{a}} \pm 4.51$ & $279.25^{\mathrm{ab}} \pm 7.81$ \\
\hline & Cobb & $186.25^{\mathrm{a}} \pm 1.84$ & $281^{\mathrm{ab}} \pm 1.47$ & $182.25^{\mathrm{a}} \pm 0.853$ & $284.50^{\mathrm{a}} \pm 8.22$ \\
\hline & Arber Acer & $182.56^{\mathrm{a}} \pm 1.22$ & $265^{\mathrm{cd}} \pm 5.93$ & $182.75^{\mathrm{a}} \pm 1.88$ & $259^{c} \pm 6.46$ \\
\hline \multirow[t]{3}{*}{$P$ values } & Temperature & 0.001 & 0.001 & 0.0001 & 0.0001 \\
\hline & Strains & 0.57 & 0.84 & 0.111 & 0.62 \\
\hline & Interaction & 0.037 & 0.005 & 0.007 & 0.040 \\
\hline
\end{tabular}

Means in the same column with different superscripts are significantly different $(P<0.05)$

\begin{tabular}{|c|c|c|c|c|c|}
\hline \multirow[t]{2}{*}{ Zone } & \multirow[t]{2}{*}{ Strain } & \multicolumn{2}{|c|}{ Alkaline phosphatase (U/l) } & \multicolumn{2}{|l|}{ Protein $(\mathrm{g} / \mathrm{dl})$} \\
\hline & & Day 21 & Day 42 & Day 21 & Day 42 \\
\hline \multirow[t]{4}{*}{ TN zone } & Ross & $17.97^{\mathrm{b}} \pm 0.40$ & $7.14^{\mathrm{c}} \pm 0.15$ & $2.93^{\mathrm{bc}} \pm 0.017$ & $3.18^{b} \pm 0.027$ \\
\hline & Hubbard & $15.5^{\mathrm{c}} \pm 0.64$ & $6.90^{c} \pm 0.341$ & $3.11^{\mathrm{a}} \pm 0.025$ & $3.33^{\mathrm{a}} \pm 0.01$ \\
\hline & Cobb & $15.58^{\mathrm{c}} \pm 0.32$ & $7.07^{\mathrm{c}} \pm 0.24$ & $3.10^{\mathrm{a}} \pm 0.022$ & $3.30^{\mathrm{a}} \pm 0.03$ \\
\hline & Arber Acer & $17.75^{\mathrm{b}} \pm 0.47$ & $7.75^{\mathrm{bc}} \pm 0.478$ & $2.95^{\mathrm{b}} \pm 0.020$ & $3.19^{\mathrm{b}} \pm 0.041$ \\
\hline \multirow[t]{4}{*}{ HAT zone } & Ross & $18.25^{\mathrm{b}} \pm 1.030$ & $10.12^{\mathrm{a}} \pm 0.21$ & $2.82^{\mathrm{cd}} \pm 0.02$ & $3.15^{\mathrm{b}} \pm 0.039$ \\
\hline & Hubbard & $21.36^{\mathrm{a}} \pm 0.95$ & $10.67^{\mathrm{a}} \pm 0.49$ & $2.80^{\mathrm{d}} \pm 0.02$ & $3.02^{\mathrm{c}} \pm 0.046$ \\
\hline & Cobb & $21^{\mathrm{a}} \pm 0.91$ & $10.68^{\mathrm{a}} \pm 0.081$ & $2.81^{\mathrm{d}} \pm 0.10$ & $3.04^{\mathrm{c}} \pm 0.045$ \\
\hline & Arber Acer & $18.5^{\mathrm{b}} \pm 0.64$ & $8.70^{\mathrm{b}} \pm 0.26$ & $2.83^{\mathrm{cd}} \pm 0.018$ & $3.10^{\mathrm{bc}} \pm 0.01$ \\
\hline \multirow[t]{3}{*}{$P$ values } & Temperature & 0.001 & 0.0001 & 0.0001 & 0.0001 \\
\hline & Strains & 0.96 & 0.194 & 0.115 & 0.72 \\
\hline & Interaction & 0.0005 & 0.0025 & 0.037 & 0.001 \\
\hline
\end{tabular}

Means in the same column with different superscripts are significantly different $(P<0.05)$ cholesterol was recorded in Ross and Arber Acer. On day 42 in TN zone, serum cholesterol was significantly $(P<0.05)$ lower and the same in Hubbard and Cobb. On day 42 , significantly $(P<0.05)$ lower and the same serum cholesterol was found in Ross and Arber Acer in HAT zone.

On day 21 in TN zone, significantly $(P<0.05)$ lower serum triglyceride was found in Hubbard and Cobb, while higher and the same triglyceride level was recorded in Ross and Arber Acer. On day 21, in HAT zone, significantly $(P<0.05)$ lower and the same triglyceride was recorded in Ross and Arber Acer. On day 42, in TN zone, no significant difference was recorded in serum triglyceride levels among the strains. In HAT zone on day 42, significantly lower $(P<0.05)$ serum triglyceride was found in Ross followed by Arber Acer, Hubbard, and Cobb.

Mean serum LDL and HDL of four different broiler strains reared in $\mathrm{TN}$ and HAT zones are presented in
Table 7. Temperature zone significantly $(P<0.05)$ affected LDL in different broiler strains on all recorded stages. On day 21 in TN zone, significantly $(P<0.05)$ lower LDL was found in Hubbard followed by Cobb, Ross, and Arber Acer. Mean LDL level was the same in Cobb, Ross, and Arber Acer in TN group on day 21. In HAT zone on day 21 , significantly $(P<0.05)$ low and the same LDL was recorded in Ross and Arber Acer. On day 42 in TN zone, no significant difference was found in mean LDL, while in HAT zone, significantly $(P<0.05)$ lower LDL was found in Ross followed by Arber Acer. On day 21 in TN zone, significantly $(P<0.05)$ higher HDL was found in Hubbard followed by Cobb while the lowest HDL level was recorded for Ross and Arber Acer. On day 21, in HAT zone, significantly $(P<0.05)$ higher serum HDL was found in Ross, while HDL level was lower and the same in all other strains. On day 42 in TN zone, significantly $(P<0.05)$ higher and the same serum HDL was found in Cobb and 
Table 5 Mean \pm SE glucose $(\mathrm{mg} / 100 \mathrm{ml})$ of different broiler strains reared in thermo-neutral and high ambient temperature zones

\begin{tabular}{llll}
\hline Zone & Strain & Day 21 & Day 42 \\
\hline TN zone & Ross & $243.5^{\mathrm{c}} \pm 3.88$ & $264.75^{\mathrm{b}} \pm 6.95$ \\
& Hubbard & $228.00^{\mathrm{d}} \pm 1.95$ & $0243.2^{\mathrm{c}} \pm 5.18$ \\
& Cobb & $224.00^{\mathrm{d}} \pm 2.85$ & $241.7^{\mathrm{c}} \pm 14.59$ \\
& Arber Acer & $235.75^{\mathrm{cd}} \pm 1.79$ & $263.00^{\mathrm{b}} \pm 5.82$ \\
HAT zone & Ross & $257.5^{\mathrm{ab}} \pm 3.94$ & $269.25^{\mathrm{b}} \pm 3.11$ \\
& Hubbard & $265.00^{\mathrm{a}} \pm 7.44$ & $289.25^{\mathrm{a}} \pm 3.52$ \\
& Cobb & $267.5^{\mathrm{a}} \pm 4.85$ & $290.25^{\mathrm{a}} \pm 2.62$ \\
& Arber Acer & $247.5^{\mathrm{bc}} \pm 5.33$ & $273.25^{\mathrm{ab}} \pm 1.65$ \\
$P$ values & Temperature & 0.0001 & 0.0001 \\
& Strains & 0.273 & 0.98 \\
& Interaction & 0.0019 & 0.002 \\
\hline
\end{tabular}

Means in the same column with different superscripts are significantly different $(P<0.05)$

Hubbard. On day 42 , in HAT zone, significantly $(P<0.05)$ higher serum HDL was recorded in Ross followed by Arber Acer, Cobb, and Hubbard.

\section{Discussion}

Temperature zone significantly affected serum AST, ALT, ALP, and protein concentration in different broiler strains at all recorded stages. The increase in serum biochemical parameters could possibly be linked to the higher production of reactive oxygen species (ROS) at cellular level. Free radicals affect blood serum metabolites [22, 24]. The increased serum ALT level may be due to the decreased antioxidative enzymes and ROS at the cellular level [21].
Decreased activity of antioxidative enzymes alters the balance between the production of ROS and the antioxidant system, which affects serum metabolites [21]. Under heat stress conditions, alteration in serum enzymes activity occurs $[11,25]$. Serum ALT level is measured clinically as a part of diagnostic liver function tests to determine liver health status, and its activities are generally increased with muscle or liver damage [26, 27].

Our findings are in agreement to the results of Kohn and Nyska [28] who reported increased AST and serum ALT level for broilers exposed to high temperature $\left(42-45^{\circ} \mathrm{C}\right)$. Our results are in line with the findings of another study, which reported increased serum activities of AST and ALT at high ambient in broiler chicks [29].

Mean serum protein in different broiler strains reared in TN and HAT zones was significantly affected by temperature zone. Significantly lower serum protein was recorded in HAT zone. Oxidative stress increases production of ROS [30-33] resulting in denaturation of biomolecules such as nucleic acid, protein, and enzymes. The reduction in serum protein may be linked to the increased oxidative stress caused by HAT, which could be partially due to the reduced intake of protein and deficiency of essential amino acids [34]. Reduced digestibility of proteins at HAT may also be responsible for low serum protein level [35]. Our results are in agreement with previous results of Faisal et al. [36] who reported that HAT decreases serum protein in Japanese quails.

Temperature zone significantly affected mean serum glucose levels of four different broiler strains at all recorded stages. Significantly higher serum glucose level was recorded at HAT. The increased blood glucose could be due to the endocrine activity of adrenal hormones, which accelerate gluconeogenesis in the cell $[37,38]$. Contrary to the findings of the resent study, Sands et al. [39] reported
Table 6 Mean \pm SE serum cholesterol $(\mathrm{mg} / \mathrm{dl})$ and serum triglyceride $(\mathrm{mg} / \mathrm{dl})$ of different broiler strains reared in thermoneutral and high ambient temperature zones

\begin{tabular}{lllllll}
\hline Zone & Strain & \multicolumn{2}{l}{ Cholesterol $(\mathrm{mg} / \mathrm{dl})$} & & \multicolumn{2}{l}{ Triglyceride $(\mathrm{mg} / \mathrm{dl})$} \\
\cline { 3 - 4 } \cline { 6 - 7 } \cline { 6 - 7 } & & Day 21 & Day 42 & & Day 21 & Day 42 \\
\hline TN zone & Ross & $127^{\mathrm{c}} \pm 3.48$ & $161.5^{\mathrm{b}} \pm 2.10$ & & $127^{\mathrm{c}} \pm 3.17$ & $124^{\mathrm{d}} \pm 1.58$ \\
& Hubbard & $118.25^{\mathrm{d}} \pm 3.25$ & $143^{\mathrm{c}} \pm 3.89$ & & $120.5^{\mathrm{d}} \pm 1.49$ & $118^{\mathrm{d}} \pm 2.27$ \\
& Cobb & $124^{\mathrm{cd}} \pm 1.95$ & $148.7^{\mathrm{c}} \pm 3.30$ & & $122.25^{\mathrm{d}} \pm 2.71$ & $120.5^{\mathrm{d}} \pm 1.93$ \\
& Arber Acer & $128.25^{\mathrm{c}} \pm 3.06$ & $162.5^{\mathrm{b}} \pm 5.97$ & & $130.2^{\mathrm{c}} \pm 2.42$ & $129^{\mathrm{d}} \pm 9.30$ \\
\multirow{2}{*}{ HAT zone } & Ross & $137.5^{\mathrm{b}} \pm 2.78$ & $170.7^{\mathrm{b}} \pm 4.13$ & & $136.25^{\mathrm{b}} \pm 1.47$ & $131.25^{\mathrm{cd}} \pm 1.88$ \\
& Hubbard & $149.75^{\mathrm{a}} \pm 2.05$ & $182.2^{\mathrm{a}} \pm 3.96$ & & $138.7^{\mathrm{a}} \pm 1.10$ & $155.25^{\mathrm{ab}} \pm 4.34$ \\
& Cobb & $146.50^{\mathrm{a}} \pm 2.25$ & $186^{\mathrm{a}} \pm 2.48$ & & $144^{\mathrm{a}} \pm 2.79$ & $158.5^{\mathrm{a}} \pm 1.19$ \\
& Arber Acer & $139.5^{\mathrm{b}} \pm 3.86$ & $165.5^{\mathrm{b}} \pm 1.70$ & & $138.7^{\mathrm{b}} \pm 1.31$ & $144.5^{\mathrm{bc}} \pm 7.58$ \\
& Temperature & 0.0001 & 0.0001 & & 0.04 & 0.001 \\
& Strains & 0.57 & 0.49 & 0.4936 & 0.094 \\
& Interaction & 0.0001 & 0.0023 & 0.003 & 0.005 \\
\hline
\end{tabular}

Means in the same column with different superscripts are significantly different $(P<0.05)$ 
Table 7 Mean \pm SE lowdensity lipoprotein (LDL) and high-density lipoprotein (HDL) of different broiler strains reared in thermo-neutral and high ambient temperature zones

\begin{tabular}{|c|c|c|c|c|c|}
\hline \multirow[t]{2}{*}{ Zone } & \multirow[t]{2}{*}{ Strain } & \multicolumn{2}{|l|}{$\mathrm{LDL}(\mathrm{mg} / \mathrm{dl})$} & \multicolumn{2}{|l|}{$\mathrm{HDL}(\mathrm{mg} / \mathrm{dl})$} \\
\hline & & Day 21 & Day 42 & Day 21 & Day 42 \\
\hline \multirow[t]{4}{*}{$\mathrm{TN}$ zone } & Ross & $172.00^{\mathrm{bc}} \pm 2.54$ & $178.00^{\mathrm{d}} \pm 3.69$ & $67.00^{\mathrm{bc}} \pm 1.15$ & $71.50^{\mathrm{b}} \pm 1.55$ \\
\hline & Hubbard & $169.00^{\mathrm{c}} \pm 1.77$ & $177.7^{\mathrm{d}} \pm 3.25$ & $73.5^{\mathrm{a}} \pm 1.19$ & $78.50^{\mathrm{a}} \pm 2.39$ \\
\hline & Cobb & $173.00^{\mathrm{bc}} \pm 2.04$ & $175.2^{\mathrm{d}} \pm 4.60$ & $71.5^{\mathrm{ab}} \pm 1.19$ & $81.00 \pm 2.85$ \\
\hline & Arber Acer & $175.2^{\mathrm{bc}} \pm 2.01$ & $183.2^{\text {cd }} \pm 2.28$ & $67.75^{\mathrm{bc}} \pm 1.37$ & $71.75^{\mathrm{b}} \pm 1.54$ \\
\hline \multirow[t]{4}{*}{ HAT zone } & Ross & $179.2^{\mathrm{b}} \pm 1.54$ & $190.2^{\mathrm{bc}} \pm 2.78$ & $66.75^{\mathrm{bc}} \pm 1.88$ & $69.25^{\mathrm{b}} \pm 1.25$ \\
\hline & Hubbard & $188.7^{\mathrm{a}} \pm 5.77$ & $206.5^{\mathrm{a}} \pm 3.47$ & $63.75^{\mathrm{c}} \pm 2.17$ & $60.75^{\mathrm{d}} \pm 2.71$ \\
\hline & Cobb & $189.7^{\mathrm{a}} \pm 0.75$ & $204^{\mathrm{a}} \pm 2.38$ & $63.5^{\mathrm{c}} \pm 1.44$ & $62.75^{\mathrm{cd}} \pm 1.37$ \\
\hline & Arber Acer & $178.2^{\mathrm{b}} \pm 1.65$ & $193.5^{\mathrm{b}} \pm 1.89$ & $64.75^{\mathrm{c}} \pm 2.28$ & $67.75^{\mathrm{bc}} \pm 2.56$ \\
\hline \multirow[t]{3}{*}{$P$ values } & Temperature & 0.0001 & 0.0001 & 0.0002 & 0.0001 \\
\hline & Strains & 0.1736 & 0.109 & 0.7367 & 0.704 \\
\hline & Interaction & 0.0140 & 0.006 & 0.0260 & 0.0006 \\
\hline
\end{tabular}

Means in the same column with different superscripts are significantly different $(P<0.05)$ that plasma glucose concentration of broilers decreases under heat stress. Our results are in contrast to the findings of Abdallh [40] who reported that plasma glucose level in broilers decreases during summer as compared to that of the winter.

High serum cholesterol levels at HAT may be caused by hyperactivity of the adrenal gland, which produces adrenocorticotropic hormones [38] for which cholesterol acts as a precursor. Our findings are in agreement with the results of Sohail et al. [10] who reported that serum cholesterol in broiler was higher under HAT than TN zone. Gursu et al. [17] found that heat stress $\left(34{ }^{\circ} \mathrm{C}\right)$ increases serum concentrations of cholesterol. The increase in serum triglyceride may be due to the overproduction of glucocorticoids and corticosterone at HAT. High ambient temperature stimulates the release of corticosterone from the adrenal glands and increases plasma concentrations of glucocorticoids in birds [27]. Glucocorticoids stimulate triglyceride synthesis in the liver by enzyme phosphatidate phosphodydrolase [41]. Our findings are in agreement with the results of Imik et al. [42] who found that serum triglyceride, LDL, and HDL were higher in broilers reared in HAT zone compared to birds reared in TN zone.

It is concluded from the present study that interaction of broiler strains and temperature zones affected the serum biochemistry. Ross and Arber Acer strains were more tolerant to summer high ambient temperature of tropical areas than Cobb and Hubbard.

Acknowledgments The authors are thankful to the Higher Education Commission (HEC) of Pakistan for funding this work through indigenous $\mathrm{PhD}$ scholarship.

\section{References}

1. Khan RU, Naz S, Nikousefat Z, Selvaggi M, Laudadio V, Tufarelli V (2012) Effect of ascorbic acid in heat-stressed poultry. World's Poult Sci J 68:477-490

2. Khan RU, Naz S, Nikousefat Z, Tufarelli V, Javadani M, Rana N, Laudadio V (2011) Effect of vitamin E in heat-stressed poultry. World's Poult Sci J 67:469-478

3. Khan RU, Naz S, Dhama K (2014) Chromium: pharmacological applications in heat stressed poultry. Int $\mathrm{J}$ Clin Pharmacol $10: 213-317$

4. Laudadio V, Dambrosio A, Normanno G, Khan RU, Naz S, Rowghani E, Tufarelli V (2012) Effect of reducing dietary protein level on performance responses and some microbiological aspects of broiler chickens under summer environmental conditions. Avian Biol Res 5:88-92

5. Khan RU, Rahman ZU, Javed I, Muhammad F (2013) Supplementation of vitamins, probioitics and proteins on oxidative stress, enzymes and hormones in post-moulted male broiler breeder. Archiv Tierzucht 61:607-616

6. Khan RU, Rahman ZU, Javed I, Muhammad F (2014) Effect of vitamins, protein level and probiotics on immune response of molted male broiler breeders. J Anim Physiol Anim Nutr 98(4):620-627

7. Khan RU, Rahman ZU, Javed I, Muhammad F (2014) Serum antioxidants and trace minerals as influenced by vitamins, protein and probiotics in male broiler breeders. J Appl Anim Res 42:249-255

8. Saqib MN, Qureshi MS, Khan RU (2018) Changes in postpartum metabolites and resumption of ovarian cyclicity in primiparous and multiparous dairy cows. Appl Biol Chem 61:107-111

9. Lin H, Decuypere E, Buyse J (2006) Acute heat stress induces oxidative stress in broiler chickens. Comp Biochem Physiol A Mol Integr Physiol 144:11-17

10. Sohail MU, Hume ME, Byrd JA, Sohail DJ, Shabbirand MZ, Rahman H (2012) Effect of supplementation of prebiotic mannan oligosaccharides and probiotic mixture on growth performance of broilers subjected to chronic heat stress. Poult Sci 91:2235-2240

11. Bartlett JR, Smith MO (2003) Effects of different levels of zinc on the performance and immunocompetence of broilers under heat stress. Poult Sci 82:1580-1588

12. Ahmad T, Mushtaq T, Mahr UN, Sarwar M, Hooge DM, Mirza MA (2006) Effect of different non-chloride sodium sources on 
the performance of heat-stressed broiler chickens. Br Poult Sci 47:249-256

13. Sahin K, Sahin N, Kucuk O (2003) Effects of chromium, and ascorbic acid supplementation on growth, carcass traits, serum metabolites, and antioxidant status of broiler chickens reared at a high ambient temperature $\left(32{ }^{\circ} \mathrm{C}\right)$. Nutr Res 23:225-238

14. Lin H, De Vos D, Decuypere E, Buyse J (2008) Dynamic changes in parameters of redox balance after mild heat stress in aged laying hens (Gallus gallus domesticus). Comp Biochem Physiol C Toxicol Pharmacol 147:30-35

15. Kral I, Suchy P (2000) Haematological studies in adolescent breeding cocks. Acta Vet Bmo 69:189-194

16. Vandendriessche J, Arnouts S (2005) Evaluation of the health status of subclinically diseased poultry by the use of blood parameters. In: 5th international colloquium on animal acute phase proteins, Dublin Ireland

17. Gursu MF, Onderci M, Gulcu F, Sahin K (2004) Effects of vitamin $\mathrm{C}$ and folic acid supplementation on serum paraoxonase activity and metabolites induced by heat stress in vivo. Nutr Res 24:157-164

18. Ziaur Rehman, Chand N, Khan RU (2017) The effect of vitamin $\mathrm{E}, \mathrm{L}$-carnitine and ginger on production traits, immune response and antioxidant status in two broiler strains exposed to chronic heat stress. Environ Sci Pollut Res 24:26851-26857

19. Chand N, Naz S, Maris H, Khan RU, Khan S, Qureshi MS (2017) Effect of betaine supplementation on the performance and immune response of heat stressed broilers. Pak J Zool 49:1857-1862

20. Rehman Z, Chand N, Khan RU, Khan S, Qureshi MS (2018) An assessment of the growth and profitability potential of meat-type broiler strains under high ambient temperature. Pak J Zool 50:429-432

21. Rahman Z, Chand N, Khan S, Khan RU (2017) Evaluating the immune response and antioxidant potential in four broiler strains under chronic high ambient temperature. Pak J Zool 49:2087-2091

22. Alhidary IA, Rahman Z, Khan RU, Tahir M (2017) Anti-aflatoxin activities of milk thistle (Silybum marianum) in broiler. World's Poult Sci J 73:559-566

23. Institute SAS (1992) SAS/STAT user's guide: statistics. SAS Institute Inc., Cary

24. Abudabos AM, Alyemni AH, Dafalla YM, Khan RU (2018) The effect of phytogenics on growth traits, blood biochemical and intestinal histology in broiler chickens exposed to Clostridium perfringens challenge. J Appl Anim Res 46:691-695

25. Abudabos AM, Alyemni AH, Dafalla YM, Khan RU (2017) Effect of organic acid blend and Bacillus subtilis alone or in combination on growth traits, blood biochemical and antioxidant status in broiler exposed to Salmonella typhimurium challenge during the starter phase. J Appl Anim Res 45:538-542

26. Alhidary IA, Abdelrahman MM, Khan RU (2016) Comparative effects of direct-fed microbial alone or with a traces mineral supplement on the productive performance, blood metabolites and antioxidant status of grazing Awassi lambs. Environ Sci Pollut Res 23:25218-25223

27. Abudabos AM, Alyemni AH, Dafallah YM, Khan RU (2016) The effect of phytogenic feed additives to substitute in-feed antibiotics on growth traits and blood biochemical parameters in broiler chicks challenged with Salmonella typhimurium. Environ Sci Pollut Res 23:24151-24157

28. Kohen R, Nyska A (2002) Oxidation of biological systems: oxidative stress phenomena, antioxidants, redox reactions, and methods for their quantication. Toxicol Pathol 30(6):620-650

29. Bhatti BM, Sardar R, Siddique B, Talat T (2003) Effect on serum enzyme concentrations and bilirubin in chicken exposed to hydropericardium virus. Pak J Vet Res 1(2):17-19

30. Majid A, Qureshi MS, Khan RU (2015) In vivo adverse effects of alpha-tocopherol on the semen quality of male bucks. J Anim Physiol Anim Nutr 99:841-846

31. Rahman H, Qureshi MS, Khan RU (2014) Influence of dietary zinc on semen traits and seminal plasma antioxidant enzymes and trace minerals of Beetal bucks. Reprod Domest Anim 48(6):1004-1007

32. Khan RU (2011) Antioxidants and poultry semen quality. World's Poult Sci J 67(2):297-308

33. Khan RU, Laudadio V, Tufarelli V (2012) Semen traits and seminal plasma biochemical parameters in White Leghorn layer breeders. Reprod Domest Anim 37:190-195

34. Laudadio V, Passantino L, Perillo A, Lopresti G, Passantino A, Khan RU, Tufarelli V (2012) Productive performance and histological features of intestinal mucosa of broiler chickens fed different dietary protein levels. Poult Sci 91(1):265-270

35. Bonnet S, Geraert PA, Lessire M, Carre B, Guillaumin S (1997) Effect of high ambient temperature on feed digestibility in broilers. Poult Sci 76:857-863

36. Faisal BA, Abdel-Fattah SA, El-Hommosany YM, Abdel-Gawad NM, Ali MF (2008) Immunocompetence, hepatic heat shock protein 70 and physiological responses to feed restriction and heat stress in two body weight lines of japanes quail. Int J Poult Sci 7:179-183

37. Qureshi MS, Akhtar S, Khan RU (2017) The effect of vitamin E and selenium on physiological, hormonal and antioxidant status of Damani and Balkhi sheep submitted to heat stress. Appl Biol Chem 60:585-590

38. Ihsanullah MS, Qureshi SM, Suhail S, Akhtar S, Khan RU (2017) Postpartum ovarian activities, blood metabolites and milk yield are influenced by changing levels of thermal stress in crossbred dairy cows. Intern J Biometerol 61:1561-1569

39. Sands JS, Smith MO (1999) Broilers in heat stress condition: effects of dietary manganese proteinate or chromium picolinate supplementation. J Appl Poult Res 8:280-2870

40. Abdalla MA, Nawal ME (2009) Effects of seasonal change in the thermal environment on physiological responses of unsexed broilers to dietary supplementation of antithyroid drug carbimazole. Middle-East J Sci Res 4:122-126

41. Lehtonen MA, Savolainen MJ, Hassinen IE (1979) Hormonal regulation of hepatic soluble phosphatidate phosphohydrolase. Induction by Cortisol in vivo and in perfused rat liver. FEBS Lett 99:162-165

42. Imik H, Kayna O, Ozkanlar S, Gumus R, Polat H, Ozkanlar Y (2013) Effects of vitamin $C$ and $\alpha$-lipoid acid dietary supplementations on metabolic adaptation of broilers to heat stress. Rev Med Vet 164(2):52-59 